\title{
Development of chitosan beads as an oil adsorbent and its application in household grease traps
}

\author{
Rawinipa Srimoon ${ }^{\mathrm{a}, *}$, Jakkapan Potipat ${ }^{\mathrm{b}}$ \\ ${ }^{a}$ Department of Applied Science and Biotechnology, Faculty of Agro-Industrial Technology, Rajamangala \\ University of Technology Tawan-Ok, Chanthaburi Campus, Chanthaburi 22210 Thailand \\ b Department of Environmental Science, Faculty of Science and Technology, Rambhaibarni Rajabhat \\ University, Chanthaburi 22000 Thailand
}

*Corresponding author, e-mail: rawinipa.srimoon@gmail.com

Received 19 Mar 2020

Accepted 7 Apr 2021

\begin{abstract}
The purpose of this research was to develop chitosan beads as an oil adsorbent in household grease traps. The results showed that chitosan beads, synthesized from $3 \% \mathrm{w} / \mathrm{v}$ chitosan flakes in $5 \% \mathrm{v} / \mathrm{v}$ acetic acid and formed the beads in $2.0 \mathrm{M} \mathrm{NaOH}$, provided the best characteristics. The white colored beads were slightly hard with maximum average weight and maximum diameter of $0.0925 \pm 0.0101 \mathrm{~g}$ and $0.67 \pm 0.06 \mathrm{~cm}$. respectively. SEM images revealed that the beads had spherical shapes and homogenously distributed pores. The maximum adsorption capacity was $1667.93 \pm 39.61 \mathrm{mg} / \mathrm{g}(83.40 \pm 1.98 \%)$ at the optimum adsorbent dosage of $10 \mathrm{~g} / \mathrm{l}$, initial oil concentration $20 \mathrm{~g} / \mathrm{l}$, pH 5 and $303 \mathrm{~K}$ with $25 \mathrm{~min}$ of contact time. The adsorption was fitted to the Langmuir adsorption isotherm. Our results indicated that the adsorption was monolayer and chemisorption, and $\mathrm{C}_{\mathrm{m}}$ increased with increasing temperature. The kinetic study was correlated with the pseudo-second order, and the intraparticle diffusion was the rate controlling step. The adsorption of oil in the household grease trap showed a significant decrease in Fat, Oil \& Grease (FOG), Biochemical Oxygen Demand (BOD), and Chemical Oxygen Demand (COD) $(p<0.05)$, while the pH did not change. Also, oil removal in real wastewater was lower than synthetic oil-in-water due to the competition for the biding sites between oil and other compositions presented in wastewater and the formation of stable micelle droplets by the surfactant. Nevertheless, the values of oil concentration in the household wastewater were lower than the standard limit of domestic discharge in Thailand, whereas the values in the treated wastewater from a noodle shop were over the standard value.
\end{abstract}

KEYWORDS: chitosan beads, oil removal, grease trap

\section{INTRODUCTION}

Fat, oil, and grease (FOG) are a group of pollutants in water which have a very low affinity to water, but they are soluble in organic solvents. FOG originates from household and restaurants, as well as from food industries [1], and can be found in wastewater. It composed of both biological and mineral oils, i.e. fatty acids, triglycerides, lubricants, diesel oils, petroleum refineries, and other hydrocarbons, with low biodegradability [2]. FOG concentration normally reaches $500 \mathrm{mg} / \mathrm{l}$, or an estimated $10 \%$ of organic pollutants found in household wastewater in Thailand; while FOG concentration collected from local restaurant wastewater is usually $1500 \mathrm{mg} / \mathrm{l}$ in average $[3,4]$. Obviously, FOG in municipal wastewater is in the form of used cooking oil, of which the free fatty acid content is less than $15 \%$ of the total oil concentration [5]. In developed countries,
FOG in the form of used cooking oil released to the environment is estimated at $2.5 \mathrm{l} /$ per person/day, which is higher than in developing countries $[6,7]$. FOG in water may have an impact in many ways ranging from clogging pipes to damaging the environment. The thin-film of oil-in-water surface limits the light penetration to the water column and the gas exchange between air-water boundary, decreasing the photosynthetic rate and dissolved oxygen in the water. The contamination of FOG also results in bioconcentration and biomagnification through the food chains. Moreover, FOG can affect wastewater treatments by forming the 'fatberg' and blocking of sewer systems $[5,8]$.

The effective treatment of FOG in wastewater is by reduction of FOG at its origins. Physical treatment, separation of the remaining FOG using equipment or certain methodologies such as grease traps, sedimentation tanks, dissolved air flotation, filtra- 
tion, ultrafiltration, electroflotation, and electrocoagulation, has been employed [8]. Grease traps are oil separation equipment used in treatment of wastewater discharged from household and restaurant kitchens. FOG in influent water is raised to the surface of the first compartment of the grease trap and, then, swept out. The efficiency of grease trap can reach 60\% removal rates [3]. Chemical treatments are usually performed after the primary treatment by adding coagulants and reagents (commonly iron and aluminum salts, polymers, and acids) into the water to emulsify or flocculate the oil-in-water [9-11]. Biological treatments, especially the activated sludge (AS), biological filters, and other biological reactors, are the most common methods used to remove the oil-in-water $[12,13]$. Among the aforementioned methods, the adsorption process is widely used in the removal of oil-in-water. The main advantages of oil adsorption by adsorbents are: its effectiveness, low cost, easy to set up systems, and no sludge produced. Several materials have been reported as oil adsorbents: polystyrene resin [14], bentonite clay [15, 16], activated carbon $[14,17]$, zeolite [18], chitosan powder, and agricultural waste materials (such as walnut shell and dead biomass) [19], palm shell [20], and rice husk [21].

Chitosan is a natural polymer of polysaccharide derived from the alkaline-deacetylation reaction of chitin, which is extracted from crustaceans, i.e. crabs and shrimps. Sub-units of chitosan are $D$-glucosamine and $N$-acetyl- $D$-glucosamine linked with $\beta$ - $(1,4)$-glycosidic bonds [22, 23]. The deacetylation of chitin is performed in an alkaline solution (commonly $>40 \% \mathrm{NaOH}$ ) at high temperatures. Chitosan is safe and biodegradable, so it is used in many applications: food industries, cosmetics, paper making industries, fertilizers, biomedical applications, and wastewater treatments [24]. Because of the presence of high porous structures and $\mathrm{pH}$ dependent amino and hydroxyl groups on the surface, chitosan has biding capacities; and it is the most common utilized adsorbent [25-27]. For examples, chitosan beads and flakes were used in the adsorption of heavy metals [28,29], biodiesel [30], phosphate [31], and dyes [32,33]. There are many morphologies of chitosan: powders, films, flakes, gels, fibers, membranes, capsules, and beads [34]. Conventional powders or flakes are not reliable due to their low stability, low density, and very fine particles. They are hard to separate or filter from the aqueous matrix [35]. Thus, chitosan beads, membranes, and other non-conventional or modified forms are more favorable.
Although the removal of oil-in-water using chitosan beads has been studied by many researchers over the years, most of them used complicated and high-cost methods. Hence, the objective of this research was to develop chitosan beads as an oil adsorbent by simple neutralization method. Moreover, this research is the first one to show that low-cost synthetic chitosan beads were able to be practically implemented to household grease traps. Therefore, the results will be useful in the development of commercial adsorbents in domestic oil-in-water treatment systems.

\section{MATERIALS AND METHODS}

\section{Preparation of chitosan beads}

Chitosan beads were prepared by the neutralization method modified from Igberase and Osifo [29] and Bekçi et al [32]. Chitosan flakes were dissolved in $5 \% \mathrm{v} / \mathrm{v}$ acetic acid at various concentrations $(1,2$, 3 , and $4 \% \mathrm{w} / \mathrm{v}$ ) and shaken at $400 \mathrm{rpm}$ over night to be completely dissolved. The chitosan solution was carefully dropped, using a dropper, into a $\mathrm{NaOH}$ solution at various concen trations $(0.1,0.5,1.0$ and $2.0 \mathrm{M}$ ) and left overnight. The coagulating chitosan beads were formed, filtered, rinsed withdistilled water, and dried at room temperature.

\section{SEM analysis}

The morphology and surface of synthetic chitosan beads were further analyzed using a Scanning electron microscope (SEM LEO 1450VP), $15 \mathrm{kV}$ at different magnifications $(13 \times$ to $20 \times)$ ). The sphericity factor (SF), to indicate the sphericity of the beads, was calculated from (1) [36].

$$
\mathrm{SF}=\frac{d_{i}}{d_{c}}
$$

where $d_{i}$ is the diameter of the maximum circular containing in the beads, and $d_{c}$ is the diameter of the minimum circular rounding the beads.

\section{Batch adsorption experiments}

Batch adsorption experiments were performed in erlenmeyer flasks using chitosan beads that were synthesized from $3 \% \mathrm{w} / \mathrm{v}$ chitosan flakes in $5 \% \mathrm{v} / \mathrm{v}$ acetic acid and formed the beads in $2.0 \mathrm{M} \mathrm{NaOH}$. The $50 \mathrm{ml}$ of palm oil-in-water sample were used, and the solutions were agitated at $400 \mathrm{rpm}$. The effect of adsorbent dosages $(5,10,20$, and $30 \mathrm{~g} / 1)$ and initial oil concentrations $(10,20,50$, and $100 \mathrm{~g} / \mathrm{l})$ on oil adsorption were conducted. The influence of contact time (in the range of $0-120 \mathrm{~min}$ ) and the $\mathrm{pH}$ 
values (varied from 3 to 11, adjusted with $0.1 \mathrm{M} \mathrm{HCl}$ or $0.1 \mathrm{M} \mathrm{NaOH}$ ) were performed. The concentration of oil was determined by solvent extraction method in a separatory funnel with hexane as a solvent. The percentage of oil removal was also calculated.

\section{$\mathrm{pH}_{\text {zpc }}$ determination}

The pHs at the point of zero charge $\left(\mathrm{pH}_{\mathrm{pzc}}\right)$ of chitosan beads were investigated according to Elanchezhiyan, Sivasurian, and Meenakshi [2]. Chitosan beads $(0.5 \mathrm{~g})$ were added to an aliquot of $50 \mathrm{ml}$ of $0.01 \mathrm{M} \mathrm{NaCl}$, and the $\mathrm{pH}$ values were adjusted (in the range of 2-12) using $0.1 \mathrm{M} \mathrm{HCl}$ or $0.1 \mathrm{M} \mathrm{NaOH}$. The initial $\mathrm{pHs}\left(\mathrm{pH}_{\text {initial }}\right)$ of the solutions were recorded. Then, the solutions were shaken at $400 \mathrm{rpm}$ for $48 \mathrm{~h}$, and the final $\mathrm{pHs}$ $\left(\mathrm{pH}_{\text {final }}\right)$ of the solutions were measured. The differences of the $\mathrm{pH}_{\text {initial }}$ and $\mathrm{pH}_{\text {final }}(\Delta \mathrm{pH})$ were calculated and plotted against the $\mathrm{pH}_{\text {initial }}$. The $\mathrm{pH}_{\text {zpc }}$ of chitosan beads was found at the intersection of the curves at $\Delta \mathrm{pH}=0$.

\section{Adsorption isotherm}

The adsorption isotherms were analyzed using the batch adsorption experiment, i.e. chitosan beads were synthesized from $3 \% \mathrm{w} / \mathrm{v}$ of chitosan flakes in $5 \% \mathrm{v} / \mathrm{v}$ acetic acid and formed the beads in $2.0 \mathrm{M} \mathrm{NaOH}$. $0.5 \mathrm{~g}$ chitosan beads were added into $50 \mathrm{ml}$ of $\mathrm{pH} 5$ oil-in-water solutions of various initial concentrations (10, 20, 50, and $100 \mathrm{~g} / \mathrm{l})$ and different temperatures (303, 323, and $333 \mathrm{~K}$ ). The solutions were shaken at $400 \mathrm{rpm}$ for $25 \mathrm{~min}$. The oil concentration at the equilibrium was then determined. The Langmuir adsorption isotherm (2) and Freundlich adsorption isotherm (3) were calculated according to Bekçi et al [32].

$$
\begin{gathered}
\frac{C_{e}}{C_{s}}=\frac{1}{C_{m} L}+\frac{C_{e}}{C_{m}}, \\
\ln C_{s}=\ln K_{f}+n_{f} \ln C_{e},
\end{gathered}
$$

where $C_{e}$ is the concentration of oil at the equilibrium $(\mathrm{mg} / \mathrm{l}), C_{s}$ is the concentration of oil adsorbed onto the adsorbent $(\mathrm{mg} / \mathrm{g}), C_{m}$ is the maximum adsorption capacity of the monolayer of the Langmuir adsorption $(\mathrm{mg} / \mathrm{g}), L$ is the Langmuir constant or adsorption energy $(1 / \mathrm{mg}), K_{f}$ is the relative adsorption capacity $(\mathrm{mg} / \mathrm{g})$, and $n_{f}$ is the adsorption intensity for heterogeneity factor of the Freundlich isotherm.

\section{Adsorption kinetics}

The adsorption kinetics was also studied using the batch adsorption experiment. $0.5 \mathrm{~g}$ of chitosan beads was added into $50 \mathrm{ml}$ of $20 \mathrm{~g} / 1$ oil-in-water samples at different temperatures $(303,323$ and $333 \mathrm{~K}$ ) and $\mathrm{pH} 5$. The solutions were shaken at $400 \mathrm{rpm}$ over time in a range of $0-120 \mathrm{~min}$. The oil concentration at the equilibrium was then determined. The adsorption kinetics was performed with respect to the pseudo-first order (4), pseudosecond order (5), and intraparticle diffusion model (6) as described by Bekçi et al [32].

$$
\begin{gathered}
\frac{1}{q_{t}}=\left(\frac{k_{1}}{q_{1}}\right)\left(\frac{1}{t}\right)+\frac{1}{q_{1}}, \\
\frac{t}{q_{t}}=\left(\frac{1}{k_{2} q_{t}^{2}}\right)+\left(\frac{1}{q_{2}}\right) t, \\
q_{t}=k_{p} t^{0.5}+C,
\end{gathered}
$$

where $q_{t}$ is the amount of oil adsorbed on the adsorbent $(\mathrm{mg} / \mathrm{g})$ at time $t(\mathrm{~min}), q_{1}$ is the maximum adsorption capacity for pseudo-first order $(\mathrm{mg} / \mathrm{g})$, $k_{1}$ is the pseudo-first order rate constant $\left(\mathrm{min}^{-1}\right)$, $q_{2}$ is the maximum adsorption capacity for pseudosecond order $(\mathrm{mg} / \mathrm{g}), k_{2}$ is the pseudo-second order rate constant $\left(\mathrm{g} / \mathrm{mg} \mathrm{min}^{-1}\right), k_{p}$ is the intraparticle

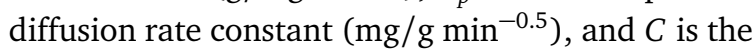
intraparticle diffusion intercept $(\mathrm{mg} / \mathrm{g})$.

\section{Oil removal efficiency in synthetic wastewater}

The optimum conditions (adsorbent dosage, initial oil concentration, $\mathrm{pH}$ of the solution, temperature, and contact time) were used to study the efficiency of oil removal in synthetic oil-in water samples. The oil concentration was determined as FOG using the solvent extraction method. Biochemical oxygen demand (BOD) was analyzed using the dilution method. Chemical oxygen demand (COD) was determined using the open reflux method. The $\mathrm{pH}$ was measured by $\mathrm{pH}$ meter (Consort C3010).

\section{Oil removal efficiency of household grease trap}

Three different household wastewater samples, two from houses and the other from a noodle shop, were investigated using grease trap at the optimum conditions, except uncontrolled $\mathrm{pH}$, temperature, and contact time. The grease trap was designed according to the Pollution Control Department [3] (Fig. S1). The outflow pipe of the kitchen sink was connected to a 171 fiber glass grease trap, which contained chitosan beads $(50 \mathrm{~g})$ in the sieve. Wastewater containing fat, oil, and grease (FOG) was fed into the system with a consistent flow rate about $1 \mathrm{l} / \mathrm{min}$ and made contact with the chitosan beads. The treated water flew through the first 


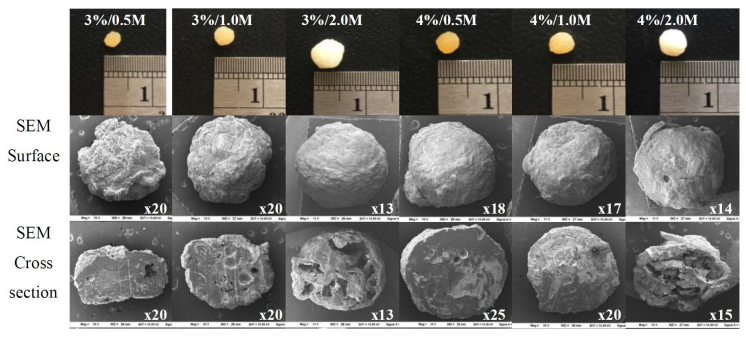

Fig. 1 The morphology and surface of synthetic chitosan beads (showing only the treatments that formed the beads: treatments $=\%$ chitosan $/$ molar of $\mathrm{NaOH}$ ).

barrier entering the second channel and the third channel, respectively. Finally, the treated wastewater flew out to a water container. The outlet water was collected for analysis of water quality parameters. The oil concentration was determined as FOG using the solvent extraction method. BOD was analyzed using the dilution method. COD was determined using the open reflux method. The $\mathrm{pH}$ was measured by $\mathrm{pH}$ meter.

\section{Statistical analysis}

All experiments were done in triplicates, and the results were presented as mean $\pm \mathrm{SD}$. The statistical analysis was evaluated by one-way analysis of variance (ANOVA), followed by the Duncan multiple range test at $p<0.05$ of significance.

\section{RESULTS AND DISCUSSION}

\section{Characterizations of chitosan beads}

Chitosan beads were synthesized by dissolving chitosan flakes $(1,2,3$, and $4 \% \mathrm{w} / \mathrm{v})$ in $5 \% \mathrm{v} / \mathrm{v}$ acetic acid and neutralized by $\mathrm{NaOH}(0.1,0.5,1.0$, and $2.0 \mathrm{M}$ ). The results showed that the beads were not formed when flakes' concentrations were $1 \%$ and $2 \% \mathrm{w} / \mathrm{v}$, while the $3 \% \mathrm{w} / \mathrm{v}$ of chitosan flakes in $2.0 \mathrm{M} \mathrm{NaOH}$ (i.e. $3 \% / 2.0 \mathrm{M}$ treatment) gave the best bead characteristics. Under these conditions, the synthetic chitosan beads are quite hard, fine, and white in color with maximum average weight and maximum diameter of $0.0925 \pm 0.0101 \mathrm{~g}$ and $0.67 \pm 0.06 \mathrm{~cm}$, respectively. The morphology and surface of chitosan beads were examined using the scanning electron microscope (SEM), and the results are shown in Fig. 1. It was demonstrated that the beads in 3\%/2.0 M treatment also generated homogenously distributed pores. The sphericity factor (SF) was 0.8708 indicating that chitosan beads were likely circular ( $\mathrm{SF}=1$ is the perfect sphere and SF $<1$ is less).
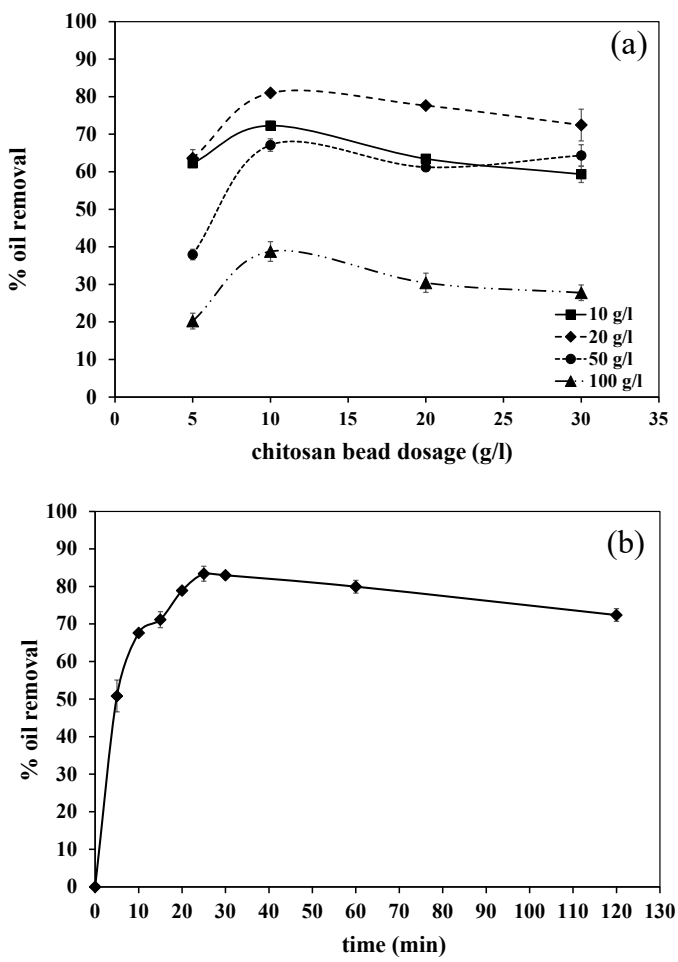

Fig. 2 The effect of (a) adsorbent dosages and initial oil concentrations, and (b) contact time on oil removal.

\section{Adsorbent dosage and initial oil concentration}

The effect of adsorbent dosages and initial oil concentrations on oil removal using chitosan beads are demonstrated in Table S1 and Fig. 2(a). The results showed that increasing the adsorbent dosage increased the percentage of oil removal significantly $(p<0.05)$ due to the availability of initial adsorption sites, and chitosan beads at $10 \mathrm{~g} / 1$ gave the highest percentage of oil removal. However, the adsorption of oil on chitosan beads beyond the concentration of $10 \mathrm{~g} / \mathrm{l}$ was significantly decreased ( $p<0.05$ ) because the vacant sites on the beads' surface adsorbed oil were almost fully occupied. Igberase and Osifo [29] also found that the adsorption of cadmium and lead on polyaniline grafted cross-linked chitosan beads did not change when the adsorbent dosage was over $4.5 \mathrm{~g} / \mathrm{l}$ due to the full occupation of metals on the beads biding sites. The results also demonstrated that the percentage of oil removal significantly increased $(p<0.05)$ with increasing initial oil concentration and attained the maximum adsorption at the concentration of $20 \mathrm{~g} / \mathrm{l}$. It meant that, at this point onward, the number of oil molecules was higher than the biding 

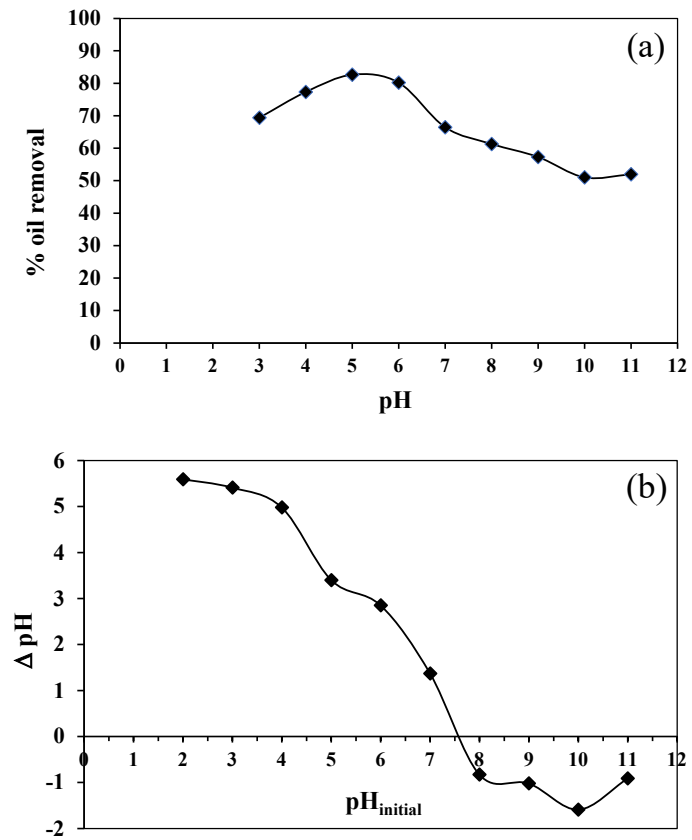

Fig. 3 The effect of (a) $\mathrm{pH}$, and (b) the $\mathrm{pH}_{\mathrm{zpc}}$ of chitosan beads on oil adsorption.

sites, and the adsorption was decreased. Hameed and El-Khaiary [37] similarly reported that the adsorption of malachite green using oil palm trunk fiber reached maximum adsorption at $25 \mathrm{mg} / \mathrm{l}$ of malachite green. Beyond this concentration, the adsorption was decreased. Therefore, the adsorption of oil on chitosan beads depends on the adsorbent dosage and initial oil concentration.

\section{Contact time}

To determine the effect of contact time on the adsorption of oil onto the chitosan beads, $10 \mathrm{~g} / \mathrm{l}$ of chitosan beads and $20 \mathrm{~g} / \mathrm{l}$ of oil concentration were used. The result is depicted in Fig. 2(b). It showed a sharp increase in the percentage of adsorption during the initial contact time and attained equilibrium at $25 \mathrm{~min}$ when the maximum adsorption was $83.40 \pm 1.98 \%$. The adsorptions between 25 30 min were not significantly different $(p>0.05)$, and percentage of adsorption was declined after $30 \mathrm{~min}$. This phenomenon was due to the fully occupied adsorption sites by oil molecules on the beads surface $[2,29]$.

\section{$\mathrm{pH}$ and $\mathrm{pH}_{\mathrm{zpc}}$}

The influence of $\mathrm{pH}$ (ranged between 3 and 11) on the oil adsorption of chitosan beads was investigated at $10 \mathrm{~g} / 1$ of adsorbent dosage, $20 \mathrm{~g} / 1$ initial oil concentration, and for 25 min contact time. The results are shown in Fig. 3(a). The results of $\mathrm{pH}_{\mathrm{zpc}}$ (using $0.01 \mathrm{M} \mathrm{NaCl}$ in the range of $\mathrm{pH} 2-12$ ) are illustrated in Fig. 3(b).

As shown in Fig. 3(a), the results revealed that the oil adsorption of chitosan beads depended on the $\mathrm{pH}$ of the solution. The highest adsorption capacity was at $\mathrm{pH} 5(82.67 \%)$. In addition, it was observed from Fig. 3(b) that the $\mathrm{pH}_{\mathrm{zpc}}$ of the chitosan beads was 7.67. It can be explained that when the $\mathrm{pH}$ was lower than $\mathrm{pH}_{\mathrm{zpc}}$, the surface of the chitosan beads was positively charged due to the protonation of amino groups of chitosan (Fig. 4(a)). Thus, by electrostatic attraction, the positive bead surface favored the adsorption of negatively charged oil molecules (Fig. 4(b)). Nevertheless, the adsorption at $\mathrm{pH}<5$ was low because the dissolution of chitosan was favorable under acidic condition. The decrease in the adsorption at $\mathrm{pH}$ beyond the $\mathrm{pH}_{\mathrm{zpc}}$ came from the repulsive force between the negative charges on the surface of the beads and the charges of the oil molecules [37].

\section{Adsorption isotherms}

The most common isotherms, the Langmuir and the Freundlich, were used to describe the adsorption of oil onto chitosan beads. Fig. 5(a,b) show the plots in the Langmuir and the Freundlich adsorption isotherms at 303,323 , and $333 \mathrm{~K}$, respectively. The isotherms constant values are shown in Table 1.

The results showed that the adsorption of oil onto the chitosan beads was fitted to the Langmuir isotherms, confirmed by the value of $R^{2}$ of the Langmuir (0.9524-0.9927) at all temperatures compared with those of the Freundlich (0.36810.4899). This implied that the oil adsorption was a monolayer on homogenous surface of the adsorbent $[37,38]$. The maximum adsorption capacity $\left(C_{m}\right)$ increased with increasing temperature, indicating that the adsorption was endothermic in nature. The results were similar to the adsorption data of cadmium and lead onto chitosan beads, i.e. the adsorption was a monolayer type, and the maximum adsorption capacity increased when the temperature increased (from 298 to $318 \mathrm{~K}$ ) [29].

The $R_{L}$ value was the dimensionless constant separation factor or equilibrium parameter, expressing the feasibility of adsorption for the Langmuir isotherm. If the $R_{L}$ value is between $0-1$, the adsorption is favorable. If the $R_{L}$ value is more than 1 , the adsorption is unfavorable. When the $R_{L}$ values are 1 and 0 , the adsorptions are linear and irreversible, respectively [39]. The $R_{L}$ value was 


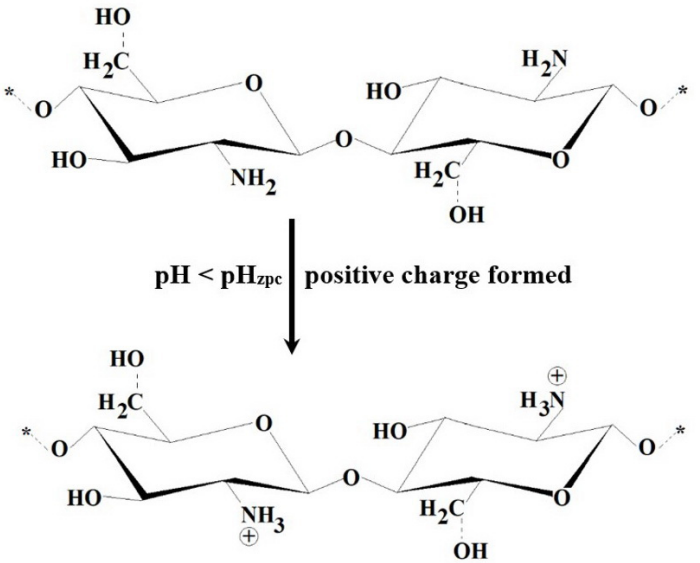

(a)

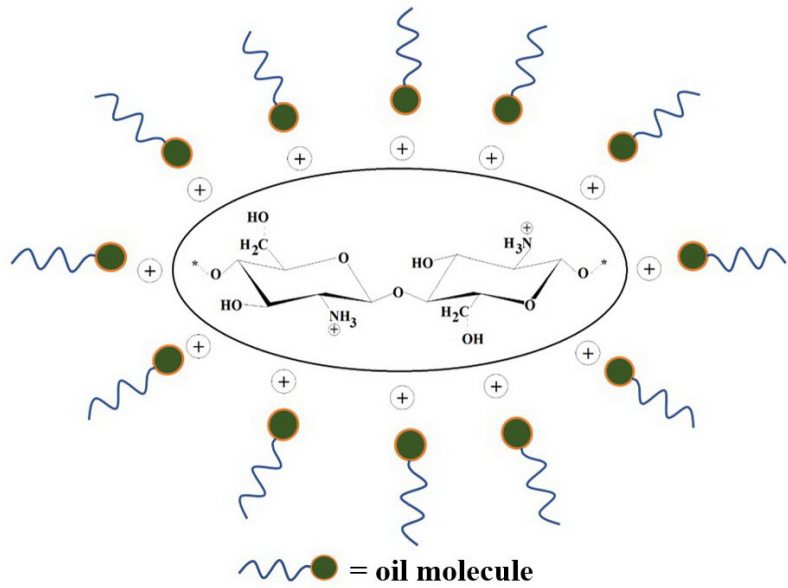

(b)

Fig. 4 (a) The protonation of amino groups of chitosan at $\mathrm{pH}<\mathrm{pH}_{\mathrm{zpc}}$ leads to the presence of positive charges on chitosan surface, and (b) the adsorption of oil molecules (negative charges) on chitosan surface (positive charges).
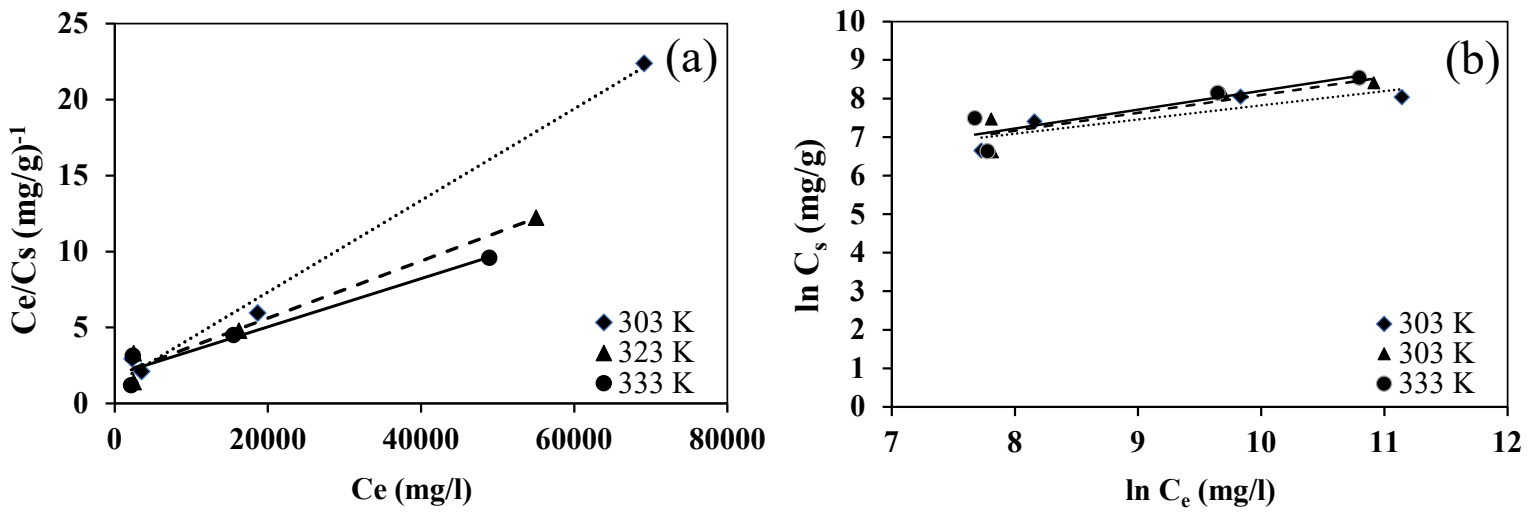

Fig. 5 (a) The Langmuir adsorption isotherms, and (b) the Freundlich adsorption isotherms.

Table 1 The Langmuir and the Freundlich isotherms' constants.

\begin{tabular}{lccccc}
\hline \multicolumn{7}{c}{ Langmuir isotherm } \\
\hline Temp. (K) & Slope & $y$-intercept & $R^{2}$ & $C_{m}(\mathrm{mg} / \mathrm{g})$ & $L(1 / \mathrm{mg})$ \\
\hline 303 & 0.0003017 & 1.2967059 & 0.9927 & 3314.551 & 0.000233 \\
323 & 0.0001881 & 1.8530300 & 0.9730 & 5316.321 & 0.000102 \\
333 & 0.0001587 & 1.8688436 & 0.9524 & 6301.197 & 0.000085 \\
\hline \multicolumn{7}{c}{ Freundlich isotherm } \\
\hline Temp. (K) & Slope & y-intercept & $R^{2}$ & & $K_{f}(\mathrm{mg} / \mathrm{g})$ \\
\hline 303 & 0.3681 & 4.1430 & 0.3681 & 0.368 & 62.992 \\
323 & 0.4628 & 3.4645 & 0.4628 & 0.463 & 31.960 \\
333 & 0.4899 & 3.3046 & 0.4899 & 0.490 & 27.238 \\
\hline
\end{tabular}



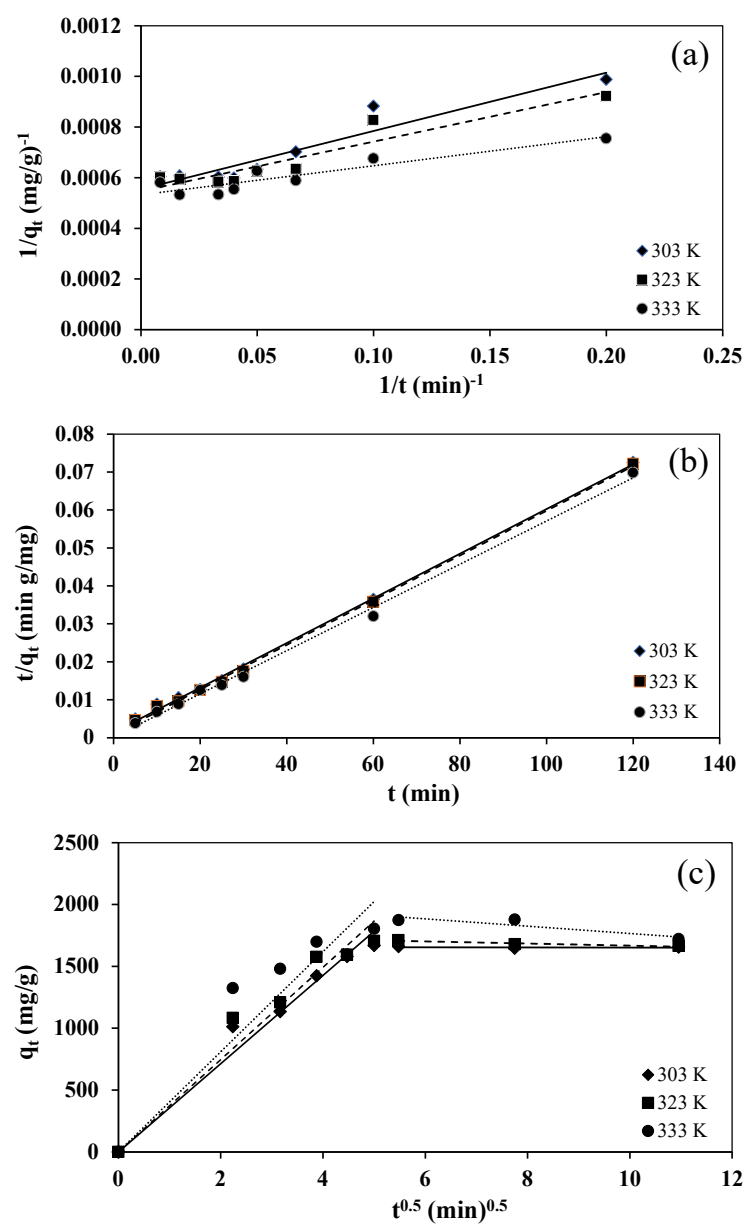

Fig. 6 (a) The pseudo-first order model, (b) the pseudosecond order model, and (c) the intraparticle diffusion model.

calculated from (7).

$$
R_{L}=\frac{1}{1+L C_{0}}
$$

where $\mathrm{C}_{0}$ is the initial oil concentration $(\mathrm{mg} / \mathrm{l})$ and $L$ is the Langmuir constant $(1 / \mathrm{mg})$. The $R_{L}$ values of the experiment were between 0 and 1 $(0.1767,0.3300$, and 0.3706 at 303,323 and $333 \mathrm{~K}$, respectively), indicating that the adsorption of oil onto chitosan beads is favorable for the Langmuir isotherm. When compared with the adsorption of other negative charges onto chitosan surface, such as phosphate $\left(\mathrm{PO}_{4}^{3-}\right)$, the data were also well fitted to the Langmuir isotherm with the $R_{L}$ values between 0 and 1 [31].

\section{Adsorption kinetics}

The pseudo-first order, pseudo-second order, and intraparticle diffusion models were used to investigate the adsorption kinetics of oil by chitosan beads. The fitted curves to the models are demonstrated in Fig. 6, and the constant values calculated from the model equations are presented in Table 2.

It was clear that the experimental data were fitted to the pseudo-second order model, which gave the highest values of $R^{2}(0.9965-0.9985)$, indicating that the adsorption showed chemisorption behavior [40]; and the adsorption between oil molecules and the beads involved an electron sharing affinity. Thus, the pseudo-second order model could be used to predict the rate at which the oil molecules are adsorbed onto chitosan beads. The rate law of the reaction may be expressed as (8).

$$
\frac{\mathrm{d} q_{e}}{\mathrm{~d} t}=k_{2}\left(q_{e}-q_{t}\right)^{2},
$$

where $q_{t}$ is the amount of oil adsorbed onto the adsorbent $(\mathrm{mg} / \mathrm{g})$ at time $t(\mathrm{~min}), q_{e}$ is the amount of oil adsorbed onto the adsorbent at the equilibrium $(\mathrm{mg} / \mathrm{g})$, and $k_{2}$ is the pseudo-second order rate constant $\left(\mathrm{g} / \mathrm{mg} \mathrm{min}^{-1}\right)$. The integration of (8) for the condition at $t=0, q_{t}=0$ gave (9)

$$
\frac{1}{\left(q_{e}-q_{t}\right)}=\frac{1}{q_{e}}+k_{2} t
$$

The maximum adsorption capacity $\left(q_{2}\right)$ and the pseudo-second order rate constant $\left(k_{2}\right)$ increased as the temperature increased from 303 to $333 \mathrm{~K}$, which implied that the adsorption capacity was temperature-dependent. It correlated with the adsorption isotherm data that the adsorption of oil onto chitosan beads was an endothermic process. The adsorption kinetic data were similar to the adsorption data of malachite green onto chitosan beads [32] and oil palm trunk fiber [37], which were well described by the pseudo-second order model.

Adsorption using porous adsorbent is usually controlled by intraparticle diffusion process. As depicted in Fig. 6(c), the plots of the amount of oil adsorbed onto chitosan beads at time $t\left(q_{t}\right)$ against the square-root of time $t\left(t^{0.5}\right)$ provided two segment lines. The first line $(t=0-25 \mathrm{~min})$ showed a sharp increase in adsorption rate and reached the maximum adsorption. It was suggested that the oil molecules were rapidly adsorbed onto the chitosan surface or diffused from the bulk solution to the biding sites on the adsorbent surface, attributed by the driving force from the concentration gradient of 
Table 2 Kinetic parameters of oil adsorption onto chitosan beads at different temperatures.

\begin{tabular}{|c|c|c|c|c|c|}
\hline \multicolumn{6}{|c|}{ The pseudo-first order } \\
\hline Temp. (K) & Slope & $y$-intercept & $R^{2}$ & $q_{1}(\mathrm{mg} / \mathrm{g})$ & $k_{1}\left(\min ^{-1}\right)$ \\
\hline 303 & 0.002302 & 0.000555 & 0.8995 & 1801.801802 & 4.147747748 \\
\hline 323 & 0.001957 & 0.000547 & 0.8827 & 1828.153565 & 3.577696527 \\
\hline 333 & 0.001148 & 0.000532 & 0.8447 & 1879.699248 & 2.157894737 \\
\hline \multicolumn{6}{|c|}{ The pseudo-second order } \\
\hline Temp. (K) & Slope & $y$-intercept & $R^{2}$ & $q_{2}(\mathrm{mg} / \mathrm{g})$ & $k_{2}\left(\mathrm{~g} / \mathrm{mg} \mathrm{min}^{-1}\right)$ \\
\hline 303 & 0.000588 & 0.001422 & 0.9984 & 1700.680272 & 0.000243139 \\
\hline 323 & 0.000589 & 0.000911 & 0.9985 & 1697.792869 & 0.000380813 \\
\hline 333 & 0.000569 & 0.000159 & 0.9965 & 1757.469244 & 0.002036233 \\
\hline \multicolumn{6}{|c|}{ The intraparticle diffusion } \\
\hline Temp. (K) & Slope & $y$-intercept & $R^{2}$ & $k_{p}\left(\mathrm{mg} / \mathrm{g} \min ^{-0.5}\right)$ & $C(\mathrm{mg} / \mathrm{g})$ \\
\hline 303 & 356.73 & 0 & 0.9671 & 356.73 & 0 \\
\hline 323 & 373.21 & 0 & 0.9445 & 373.21 & 0 \\
\hline 333 & 404.79 & 0 & 0.8531 & 404.79 & 0 \\
\hline
\end{tabular}

oil and vacant sites on the surface of beads [27]. This indicated that the initial time of adsorption was controlled by the intraparticle diffusion process, i.e. the adsorption rate controlling step. Besides, the intraparticle diffusion constant $\left(k_{p}\right)$ increased with increasing temperature. On the contrary, the latter segment line $(t>25 \mathrm{~min})$ showed constant adsorption, due to the lack of available sites on the adsorbent surface.

\section{Oil removal efficiency in synthetic wastewater}

The optimum adsorption conditions $(10 \mathrm{~g} / \mathrm{l}$ of adsorbent, $20 \mathrm{~g} / \mathrm{l}$ oil concentration, $25 \mathrm{~min}$ of contact time, at $303 \mathrm{~K}$, and $\mathrm{pH} 5$ ) were used in order to obtain efficiency in the oil removal in the synthetic oil-in-water sample. The result revealed that the maximum adsorption was $83.40 \pm 1.98 \%$ or $1667.93 \pm 39.61 \mathrm{mg} / \mathrm{g}$.

\section{Oil removal efficiency in the household grease trap}

Chitosan beads were practically applied to the household grease trap at different on-site household wastewater samples to determine oil removal at optimum conditions, except uncontrolled $\mathrm{pH}$, temperature and contact time. Oil concentrations (in term of FOG, BOD, COD, and $\mathrm{pH}$ of the influent and effluent water were analyzed (Table S2). Oil concentration, BOD, and COD in effluent water decreased significantly $(p<0.05)$ when the influent water had passed through the grease trap using chitosan beads as the adsorbent. The percentage of oil reduction of the 6-occupant household was the highest (71.01\%), followed by the 2-occupant household (66.99\%) and the noodle shop (54.19\%). BOD and COD also decreased in the similar sequences. The $\mathrm{pH}$ of treated and untreated wastewater from the 2-occupant household and the noodle shop were significantly different $(p<0.05)$, whereas the $\mathrm{pH}$ of the 6-occupant household was not $(p>0.05)$. The results indicated that the efficiency of oil removal in real wastewater samples were lower than those of the synthetic oil-in-water samples. It might be due to the competition between oil molecules and other substances which can be adsorbed by chitosan beads. In addition, the emulsified oil by surfactants led to the formation of more stable oil droplets, hindering the adsorption of oil molecules onto the surface of chitosan. Pintor et al [8] reported that the surface-active agents influenced the stability of oil-in-water, the higher concentration of surfactants, the more stable oil-emulsion. Moreover, the adsorption of oil in synthetic water was performed in the batch experiment with 25 min of contact time, while the adsorption of oil in real wastewater in the grease trap was the continuous mode. Wastewater was fed to the grease trap with an uncontrolled flow rate (about $1 \mathrm{l} / \mathrm{min}$ in average), thus the adsorption could not attain the equilibrium as compared with the laboratory experiment. This occurrence made a considerable point for further research to improve the oil removal from household wastewater using grease traps. According to the reports of the Pollution Control Department of Thailand, the 
household grease trap can reduce fat, oil and grease by $60 \%$ [3]. The problems from FOG in domestic wastewater have generally been controlled because FOG is restricted from activities such as cleaning and cooking. In this research, oil concentration, as FOG and BOD, in the household effluent water were below the discharge limit of Type-d buildings (household) defined by Thai legislation (i.e. FOG < $20 \mathrm{mg} / \mathrm{l}$ and $\mathrm{BOD}<50 \mathrm{mg} / \mathrm{l}$ ), and the noodle shop's were over the discharge limit of Type-e buildings (restaurant) [41].

\section{CONCLUSION}

Development of chitosan beads as an oil adsorbent in household grease traps showed that the conducive conditions for bead synthesis were $3 \% \mathrm{w} / \mathrm{v}$ chitosan flakes in $5 \% \mathrm{v} / \mathrm{v}$ acetic acid and formed the beads in $2.0 \mathrm{M} \mathrm{NaOH}$. The obtained beads were slightly hard and spherical in shapes with homogenously distributed pores. The maximum adsorption capacity was $1667.93 \pm 39.61 \mathrm{mg} / \mathrm{g}$ $(83.40 \pm 1.98 \%)$ occurred at the adsorbent dosage $=10 \mathrm{~g} / \mathrm{l}$, initial oil concentration $=20 \mathrm{~g} / \mathrm{l}$, equilibrium time $=25 \mathrm{~min}, \mathrm{pH}=5$, and $303 \mathrm{~K}$. The adsorption was better described by the Langmuir isotherm, suggesting monolayer adsorption type. The adsorption kinetics was fitted very well with the pseudo-second order, and the rate controlling step was intraparticle diffusion. The adsorption of oil onto the chitosan beads in the household grease trap using real wastewater showed a significant decrease in FOG, BOD and COD $(p<0.05)$. However, the percentage of oil removal in real wastewater was significantly lower than in synthetic wastewater because of the competition between the oil and other substances in the real wastewater. Moreover, the formation of stable micelles by the surfactants reduced the adsorption of oil onto the adsorbent. Therefore, it is necessary to develop more methods and use them in couple with the adsorption method to improve the reduction of oily wastewater.

\section{Appendix A. Supplementary data}

Supplementary data associated with this article can be found at http://dx.doi.org/10.2306/ scienceasia1513-1874.2021.046.

Acknowledgements: This research was supported by the grant of Rajamangala University of Technology Tawan-Ok, Thailand. The authors would like to thanks the Microscopic Center, Faculty of Science, Burapha University, Chonburi Province, Thailand, for SEM assistance.

\section{REFERENCES}

1. Del Mundo DMN, Sutheerawattananonda M (2017) Influence of fat and oil type on the yield, physicochemical properties, and microstructure of fat, oil, and grease (FOG) deposits. Water Res 124, 308-319.

2. Elanchezhiyan SSD, Sivasurian N, Meenakshi S (2014) Recovery of oil from oil-in-water emulsion using biopolymers by adsorptive method. Int $J$ Biol Macromol 70, 399-407.

3. Pollution Control Department (2008) Management Guidelines for Oil and Fat from Household Grease Trap and Utilization, TQP Printing Ltd, Bangkok.

4. Pollution Control Department (2008) Management Guidelines for Oil and Fat from Restaurant Grease Trap and Utilization, TQP Printing Ltd, Bangkok.

5. Wallace T, Gibbons D, O'Dwyer M, Curran TP (2017) International evolution of fat, oil and grease (FOG) waste management: A review. J Environ Manage 187, 424-435.

6. European Biomass Industry Association (2015) Transformation of used cooking oil into biodiesel: From waste to resource. In: Promotion of Used Cooking Oil Recycling for Sustainable Biodiesel Production, Intelligent Energy Europe, Brussels.

7. Williams JB, Clarkson C, Mant C, Drinkwater A, May E (2012) Fat, oil and grease deposits in sewers: Characterization of deposits and formation mechanisms. Water Res 46, 6319-6328.

8. Pintor AMA, Vilar VJP, Botelho CMS, Boaventura RAR (2016) Oil and grease removal from wastewaters: sorption treatment as an alternative to state-of-theart technologies: A critical review. Chem Eng $J$ 297, 229-255.

9. Chipasa KB (2001) Limits of physicochemical treatment of wastewater in the vegetable oil refining industry. Polish J Environ Stud 10, 141-147.

10. Cristóvão RO, Botelho CM, Martins RJE, Loureiro JMR, Boaventura AR (2014) Primary treatment optimization of a fish canning wastewater from a Portuguese plant. Water Res Ind 6, 51-63.

11. Cristóvão RO, Botelho CM, Martins RJE, Loureiro JM, Boaventura RAR (2015) Fish canning industry wastewater treatment for water reuse-a case study. $J$ Cleaner Prod 87, 603-612.

12. Souza BM, Cerqueira AC, Sant'Anna GL, Dezotti M (2011) Oil-refinery wastewater treatment aiming reuse by advanced oxidation processes (AOPs) combined with biological activated carbon (BAC). Ozone Sci Eng 33, 403-409.

13. Sharghi EA, Bonakdarpour B, Roustazade P, Amoozegar MA, Rabbani AR (2013) The biological treatment of high salinity synthetic oilfield produced water in a submerged membrane bioreactor using a halophilic bacterial consortium. Chem Technol Biotechnol 88, 2016-2026.

14. Zhou YB, Tang XY, Hu XM, Fritschi S, Lu J (2008) 
Emulsified oily wastewater treatment using a hybridmodified resin and activated carbon system. Sep Purif Technol 63, 400-406.

15. Al-Malah K, Azzam MOJ, Abu-Lail NI (2000) Olive mills effluent (OME) wastewater post-treatment using activated clay. Sep Purif Technol 20, 225-234.

16. Moazed H, Viraraghavan T (2005) Use of organoclay/anthracite mixture in the separation of oil from oily waters. Energy Sources 27, 101-112.

17. Ahmad AL, Sumathi S, Hameed BH (2005) Residual oil and suspended solid removal using natural adsorbents chitosan, bentonite and activated carbon: A comparative study. Chem Eng $J$ 108, 179-185.

18. Santi CA, Cortes S, D’Acqui LP, Sparvoli E, Pushparaj B (2008) Reduction of organic pollutants in olive mill wastewater by using different mineral substrates as adsorbents. Bioresour Technol 99, 1945-1951.

19. Srinivasan A, Viraraghavan T (2010) Oil removal from water using biomaterials. Bioresour Technol 101, 6594-6600.

20. Ngarmkam W, Sirisathitkul C, Phalakornkule C (2011) Magnetic composite prepared from palm shell-based carbon and application for recovery of residual oil from POME. $J$ Environ Manage 92, 472-479.

21. Razavi Z, Mirghaffari N, Rezaei B (2015) Performance comparison of raw and thermal modified rice husk for decontamination of oil polluted water. CLEAN-Soil Air Water 43, 182-190.

22. Bedian L, Villalva-Rodríguez AM, Hernández-Vargas G, Parra-Saldivar R, Iqbal HMN (2017) Bio-based materials with novel characteristics for tissue engineering applications: A review. Int $J$ Biol Macromol 98, 837-846.

23. Lizardi-Mendoza J, Monal WMA, Valencia FMG (2016) Chemical characteristics and functional properties of chitosan. In: Bautista-Banos S, Romanazzi G, Jiménez-Aparicio A (eds) Chitosan in the Preservation of Agricultural Commodities, Academic Press Elsevier Inc, Cambridge, pp 3-31.

24. Muxika A, Etxabide A, Uranga J, Guerrero P, De La Caba K (2017) Chitosan as a bioactive polymer: Processing, properties and applications. Int $J$ Biol Macromol 105, 1358-1368.

25. Singh A, Mittal A, Benjakul S (2021) Chitosan nanoparticles: Preparation, food applications and health benefits. ScienceAsia 47, 1-10.

26. Faikrua A, Jeenapongsa R, Sila-asna M, Viyoch J (2009) Properties of $\beta$-glycerol phosphate/collagen/chitosan blend scaffolds for application in skin tissue engineering. ScienceAsia 35, 247-254.

27. Mahaninia MH, Wilson LD (2017) Phosphate uptake studies of cross-linked chitosan bead materials. $J$ Colloid Interf Sci 485, 201-212.

28. Sananmuang R, Udnan Y, Chuachuad W (2008) Removal of iron in synthetic ground water by chitosan membrane. NU Int J Sci 5, 200-209.

29. Igberase E, Osifo P (2015) Equilibrium, kinetic, thermodynamic and desorption studies of cadmium and lead by polyaniline grafted cross-linked chitosan beads from aqueous solution. $J$ Ind Eng Chem 26, 340-347.

30. Pitakpoolsil W, Hunsom M (2013) Adsorption of pollutants from biodiesel wastewater using chitosan flakes. $J$ Taiwan Inst Chem Eng 44, 963-971.

31. Liu X, Zhang L (2015) Removal of phosphate anions using the modified chitosan beads: Adsorption kinetic, isotherm and mechanism studies. Powder Technol 277, 112-119.

32. Bekçi Z, Özveri C, Seki U, Yurdakoç K (2008) Sorption of malachite green on chitosan bead. $J$ Hazard Mater 154, 254-261.

33. Boardman SJ, Lad R, Green DC, Thornton PD (2017) Chitosan hydrogels for targeted dye and protein adsorption. J Appl Polym Sci 134, 44846-44856.

34. Krajewska B (2004) Application of chitin-and chitosan-based materials for enzyme immobilizations: A review. Enzyme Microb Tech 35, 126-139.

35. Budi S, Suliasih BA, Rahmawati I, Erdawati (2020) Size-controlled chitosan nanoparticles prepared using ionotropic gelation. ScienceAsia 46, 457-461.

36. Chan ES, Lee BB, Ravindra P, Poncelet D (2009) Prediction models for shape and size of ca-alginate macrobeads produced through extrusion-dripping method. J Colloid Interf Sci 338, 63-72.

37. Hameed BH, El-Khaiary MI (2008) Batch removal of malachite green from aqueous solutions by adsorption on oil palm trunk fibre: Equilibrium isotherms and kinetic studies. J Hazard Mater 154, 237-244.

38. Hena S (2010) Removal of chromium hexavalent ion from aqueous solutions using biopolymer chitosan coated with poly 3-methyl thiophene polymer. $J$ Hazard Mater 181, 474-479.

39. Weber TW, Chakravort RK (1974) Pore and solid diffusion models for fixed-bed adsorbers. AIChE J 20, 228-232.

40. Igberase E, Osifo P, Ofomaja A (2014) The adsorption of copper(II) ions by polyaniline graft chitosan beads from aqueous solutions: Equilibrium, kinetic and desorption studies. J Environ Chem Eng 2, 362-369.

41. Ministry of Natural Assets and the Environment (2005) Standards regulate sewerage from some building types and sizes. In: The Government Gazette dated December 29, 2005 part 125 122, pp 4-10. 


\section{Appendix A. Supplementary data}

Table S1 Percentage of oil removal at different adsorbent dosage and initial oil concentration $(n=3)$.

\begin{tabular}{lcccc}
\hline Chitosan beads & \multicolumn{4}{c}{ Initial oil concentration $(\mathrm{g} / \mathrm{l})$} \\
\cline { 2 - 5 } dosage $(\mathrm{g} / \mathrm{l})$ & 10 & 20 & 50 & 100 \\
\hline 5.0 & $62.28 \pm 1.02^{\mathrm{a}, 1}$ & $63.60 \pm 2.30^{\mathrm{b}, 1}$ & $37.94 \pm 1.40^{\mathrm{c}, 1}$ & $20.24 \pm 2.11^{\mathrm{d}, 1}$ \\
10.0 & $72.27 \pm 1.18^{\mathrm{a}, 2}$ & $81.00 \pm 0.69^{\mathrm{b}, 2}$ & $67.14 \pm 1.66^{\mathrm{c}, 2}$ & $38.78 \pm 2.63^{\mathrm{d}, 2}$ \\
20.0 & $63.48 \pm 0.64^{\mathrm{a}, 3}$ & $77.63 \pm 0.63^{\mathrm{b}, 3}$ & $61.23 \pm 1.15^{\mathrm{c}, 3}$ & $30.41 \pm 2.56^{\mathrm{d}, 3}$ \\
30.0 & $59.35 \pm 2.19^{\mathrm{a}, 4}$ & $72.46 \pm 4.22^{\mathrm{b}, 4}$ & $64.34 \pm 2.88^{\mathrm{c}, 4}$ & $27.77 \pm 2.09^{\mathrm{d}, 4}$ \\
\hline
\end{tabular}

The superscript letters $(\mathrm{a}, \mathrm{b}, \mathrm{c}, \mathrm{d})$ in each row show the significant differences $(p<0.05)$.

The superscript numbers $(1,2,3,4)$ in each column show the significant differences $(p<0.05)$.

Table S2 Removal of oil as FOG, BOD, COD, and $\mathrm{pH}$ in real wastewater using the grease trap with chitosan beads $(n=3)$.

\begin{tabular}{lcccc}
\hline Sample & Parameter & Before & After & \%Removal \\
\hline 2-occupant household & FOG (mg/l) & $7.70 \pm 0.49^{\mathrm{a}}$ & $2.54 \pm 0.07^{\mathrm{b}}$ & 66.99 \\
& BOD (mg/l) & $26.97 \pm 1.95^{\mathrm{a}}$ & $9.27 \pm 0.07^{\mathrm{b}}$ & 65.64 \\
& COD (mg/l) & $110.17 \pm 11.12^{\mathrm{a}}$ & $37.78 \pm 0.92^{\mathrm{b}}$ & 65.71 \\
& $\mathrm{pH}$ & $6.12 \pm 0.05^{\mathrm{a}}$ & $6.34 \pm 0.06^{\mathrm{a}}$ & -3.54 \\
\hline 6-occupant household & FOG (mg/l) & $45.77 \pm 1.74 \mathrm{a}$ & $13.27 \pm 0.65 \mathrm{~b}$ & 71.01 \\
& BOD (mg/l) & $135.24 \pm 4.08^{\mathrm{a}}$ & $37.34 \pm 1.54^{\mathrm{b}}$ & 72.39 \\
& COD (mg/l) & $543.19 \pm 20.59^{\mathrm{a}}$ & $152.23 \pm 15.08^{\mathrm{b}}$ & 71.97 \\
\hline a noodle shop & pH & $7.02 \pm 0.18^{\mathrm{a}}$ & $7.06 \pm 0.17^{\mathrm{a}}$ & -0.62 \\
& FOG (mg/l) & $3,598.06 \pm 315.85^{\mathrm{a}}$ & $1,648.40 \pm 182.05^{\mathrm{b}}$ & 54.19 \\
& BOD (mg/l) & $25,062.04 \pm 3,132.19^{\mathrm{a}}$ & $12,116.24 \pm 1,465.34^{\mathrm{b}}$ & 51.66 \\
& COD (mg/l) & $54,819.97 \pm 3,451.98^{\mathrm{a}}$ & $26,276.73 \pm 1,133.67^{\mathrm{b}}$ & 52.07 \\
& pH & $7.74 \pm 0.26^{\mathrm{a}}$ & $7.05 \pm 0.75^{\mathrm{b}}$ & 8.96 \\
\hline
\end{tabular}

The superscript letters $(\mathrm{a}, \mathrm{b})$ in each row show the significant differences $(p<0.05)$.

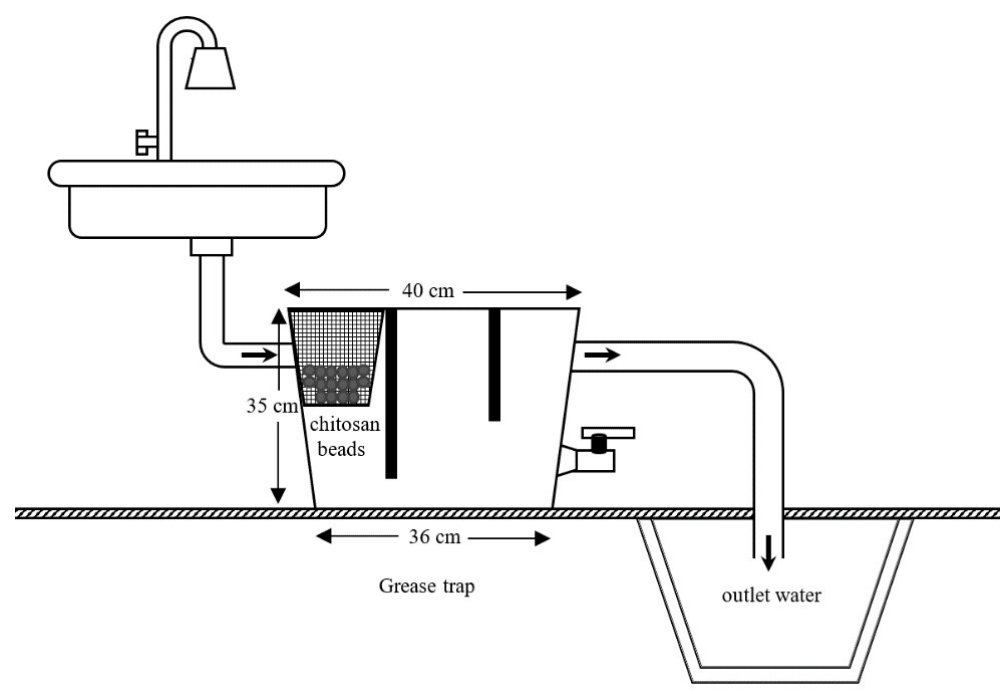

Fig. S1 Diagram of the grease trap in the experiment. 